\title{
SOEDJONO HOEMARDANI AND INDONESIAN-JAPANESE RELATIONS $1966-1974^{1}$
}

\author{
Michael Malley
}

The first several years of the New Order witnessed the ascendance and subsequent decline of the so-called "financial generals," among whom the most prominent were Alamsjah Prawiranegara and Soedjono Hoemardani. Both men were members of President Suharto's staff of personal assistants, and both had ties to him which stretched back many years. Soedjono had been Suharto's chief finance officer during the late 1950s when he commanded the Diponegoro Division, and during the early 1960s Alamsjah had served with Suharto in the Army's headquarters in Jakarta. At that time, Alamsjah had been Assistant 7/Finance and Soedjono had been a member of his staff. The special relationship which existed between Suharto and the two men was evident in the composition of the group of people with whom Suharto surrounded himself. Colonel Soedjono Hoemardani was just as frequently at Suharto's side as General Alamsjah and various other generals, such as Kartakusuma and Daryatmo, who accompanied the president to important meetings. ${ }^{2}$ In July or August 1966, about five months after he was named acting president, but still several months before Sukarno would vacate the position of president, Suharto formed a "personal staff" (Staf Pribadi, Spri) of some eighteen advisers, consisting of six army officers and two teams of civilians. Soedjono was one of three junior officers who served as a member of the Spri under the direction of General Alamsjah who, significantly, has been described as the "epitome of the military entrepreneur."3

\footnotetext{
${ }^{1}$ The writer would like to acknowledge the assistance which he has received in the preparation of this paper and in the conduct of related, ongoing research. In particular, Benedict Anderson and Donald Emmerson have offered comments on Soedjono's life and military career, Takashi Shiraishi has located and translated articles from Japanese newspapers, as well as commenting on Japan's relations with Indonesia, Franklin Weinstein and Ann Gregory have kindly provided notes from interviews they conducted with Soedjono, and Francisia Seda has offered her assistance in unraveling the complexity of the Asahan project negotiations. Of course, all errors in the article remain the author's.

${ }^{2}$ See for example, Angkatan Bersendjata, July 11-13, 1966 and Kompas, July 11-13, 1966.

${ }^{3}$ Harold Crouch, The Army and Politics in Indonesia (Ithaca: Cornell University Press, 1977), p. 243.
} 
Despite the fact that he began his career in the New Order as Alamsjah's subordinate, Soedjono not only outlasted him as a close presidential adviser, but also usurped his role as Suharto's principal contact with Japan. For Soedjono, this was a coup, for it came at the point when Indonesia's relations with Japan were being rebuilt and were on the verge of a tremendous expansion. Moreover, because of the turbulence affecting the Indonesian government during the late 1960s and early 1970s as the New Order was established and Suharto attempted to assert his own authority, many aspects of government tended to be dealt with on an ad hoc basis, outside formal channels of government but with presidential authorization. Consequently, Soedjono's position as a presidential adviser, without a formal ministerial role, placed him in an advantageous location from which to become involved not only in domestic affairs, but in international ones as well. His background in military finance, and his success in assisting Suharto financially in the 1950s, promised him the trust and support of his commander-turned-president for further financial initiatives under the New Order.

From the very beginning of the New Order, Soedjono traveled to those countries which were most important to Indonesia in achieving its goals of economic stabilization and development. In September 1966, he undertook his first foreign trip since returning in 1964 from a ten month course at the US Army's Finance School at Fort Benjamin Harrison, Indianapolis. This time, he traveled to the Netherlands, the United States, and Japan with Foreign Minister Adam Malik's delegation which in New York announced Indonesia's decision to return to the United Nations. Shortly before departing for the Netherlands to join Malik, according to Soedjono, he queried President Suharto regarding what the delegation should do when it appeared at the United Nations; Suharto's answer, he claimed, was only one word: "Masuk" ("Enter"). ${ }^{4}$ Soedjono thus rejected the notion that Suharto's concern not to offend Sukarno made him more reluctant than Malik to rejoin the international body. By adding that "I am the one who knows about this, only me, no one else," 5 Soedjono also emphasized, albeit indirectly, his closeness to the president in matters of the greatest political significance.

While in the United States, Soedjono accompanied Malik and Anwar Sani, the director general of the Indonesian Foreign Office, to a meeting at the White House with President Lyndon B. Johnson and two of his advisers, Walt Rostow and William Jorden, as well as the US ambassador to Indonesia, Marshall Green. ${ }^{6}$ Although large portions of the record of their discussion remain classified, it appears that President Johnson was most interested in the issue of communism in Southeast Asia. In particular, he asked about Indonesia's view of the Vietnam conflict, what Indonesia thought the United States might do to resolve it, and "whether, in the Foreign Minister's opinion, the Communists had been decisively beaten in Indonesia." Unfortunately, the Indonesian responses have been excised and, from the available material, it does not appear that Soedjono played an active role in the meeting. ${ }^{7}$

\footnotetext{
${ }^{4}$ Franklin Weinstein, "Notes of interviews with Soedjono," December 10, 1969, p. 15.

$5_{\text {Ibid. }}$

${ }^{6}$ US Department of State, Memorandum of Conversation, 27 September 1966; in Declassified Documents Quarterly Catalog: 1982 8, 4 (October-December 1982), microfiche no. 002522.

${ }^{7}$ Soedjono claimed to have visited the United States again in 1967 at the invitation of the State Department; but no corroborative evidence is available on this point. A declassified, but heavily sanitized, White House memorandum, indicates that an Indonesian delegation called on Walt Rostow on July 18, 1967 to request, on behalf of Suharto, "White House assistance in connection with Indonesian aid needs." It is entirely possible that Soedjono was among that delegation and that it was the visit to which he referred. White House
} 
After leaving the United States, the delegation flew to Tokyo, where Soedjono was introduced for the first time to members of the influential "Indonesia lobby" in Japan, among them Nakajima Shinzaburo, a businessman with close ties to Indonesia, Kimura Takeo, a conservative politician and head of the Cabinet Secretariat, and Fukuda Takeo, the minister of finance. Probably because of Nakajima's former role as a supporter of the PRRI-Permesta rebels, " Soedjono became distinctly "nervous" when questioned about who had introduced him to Nakajima. However, he was at pains to differentiate the nature of Indonesia's ties to Japan under the New Order from the "mutual suspicion," caused by "dirty practices," which he said had characterized the two countries' relations during the Sukarno years. As a consequence of the Sukarno period's legacy, Soedjono claimed, it was not until 1969 that Indonesia "achieved smooth relations with Japan."

While Indonesia's relations with Japan may have improved only slowly, Soedjono seems to have moved very quickly to establish himself as an important intermediary between the New Order government and Japan's Indonesia lobby. At some point in 1967, he received a visit from Kubota Yutaka regarding the possibility of resuming the construction of the Asahan hydro-electric generating-cum-aluminum smelting project in Sumatra which had been discontinued in 1963 following the departure of a Russian team. Kubota had been interested in the development of the Asahan river's hydro-electric potential since the late 1930s, and during World War II had headed the Japanese occupation's Sumatran Water Resources Development Survey Mission. Immediately following the war he had established the engineering consulting firm Nippon Koei and, during the 1950s, had lobbied, albeit unsuccessfully, for an Asahan river development project to be included in Japan's reparations payments to Indonesia. However, his firm had "gained nearly an exclusive hold over Indonesia's infrastructure projects under the reparations fund." 10 According to A. R. Soehoed, later chairman of the Asahan project, in 1967 Kubota visited Soedjono in Jakarta to propose that he begin again to research the Asahan project, this time with financing provided by Nippon Koei. Soedjono apparently agreed and, "with the blessing of Acting President Suharto," Kubota received permission to resume his research into the project. ${ }^{11}$

Why Kubota approached Soedjono in this matter is open to speculation. However, it would appear that Soedjono's meeting with members of the Indonesia lobby during his visit to Japan in 1966 had produced useful contacts. One possibility is that Kimura, later known as a strong supporter of the Asahan project, ${ }^{12}$ had recommended to Kubota that Soedjono would be receptive to approaches by interested Japanese investors. However,

Memorandum for the Record, 19 July 1967; in Declassified Documents Quarterly Catalog: 1985, no. 11, Vol.1 (January-March 1985), microfiche no. 000611.

8PRRI (Pemerintah Revolusioner Republik Indonesia-Revolutionary Government of the Republic of Indonesia) was the Sumatra-based branch of the 1958 regional rebellion against the Sukarno government. Permesta (Perjuangan Semesta Alam-Inclusive Struggle) was the name used by the rebels based in Sulawesi.

${ }^{9}$ Weinstein, "Notes of interviews," February 26, 1973, p. 1.

${ }^{10}$ Masashi Nishihara, The Japanese and Sukarno's Indonesia: Tokyo-Jakarta Relations, 1951-1966 (Kyoto: Kyoto University Press, 1976; and Honolulu: University Press of Hawaii, 1976), pp. 66-67, 103.

${ }^{11}$ A.R. Soehoed, Asahan: Impian yang menjadi kenyataan (Jakarta: privately published, 1983), p. 31.

${ }^{12}$ Kimura is best known for his statement during a visit to the project some time in the early 1970 s that he would commit hara kiri if the project were not completed successfully as a cooperative Japanese-Indonesian venture. Bisuk Siahaan, Sejarah pembangunan proyek Asahan: Membangunkan raksasa sedang tidur (Jakarta: privately published, 1984), p. 217. 
other information points to his reliance on former PRRI/Permesta rebel officers who had sought support from right-wing Japanese in their opposition to Sukarno during the late 1950s. According to a brief paper written by three conservative Japanese businessmen, including Nakajima, whom Soedjono acknowledged having met in 1966, Jan Walandouw was the one who introduced Kubota to Soedjono. ${ }^{13}$

In response to criticism of the business activities in which some of his close assistants were alleged to be engaged, President Suharto "disbanded" his personal staff in mid-June 1968; however, three members of that staff-all army officers-were reappointed immediately as personal assistants (Asisten Pribadi, Aspri), ${ }^{14}$ and the institution remained essentially unchanged. What did begin to change, however, was the power balance among the Aspri. Notably, Alamsjah had not been reappointed as an Aspri, as had Soedjono and Ali, although he did retain the position of state secretary to which he had been appointed at the end of January. ${ }^{15}$ That Alamsjah's position in the inner circle of presidential advisers began to decline in early to mid-1968 is well known. ${ }^{16}$ In addition to the fact that this occurred, the reasons why it happened are of special importance for understanding how and into what areas the influence of Soedjono expanded in the next few years.

In the months preceding the dissolution of the Spri, Soedjono's influence had received a boost as a result of a serious miscalculation by Alamsjah which not only led, ultimately, to Alamsjah's downfall, but also limited his influence in a rapidly expanding area of Indonesian foreign relations-economic diplomacy vis-à-vis Japan. By late January 1968, it had become public knowledge that Acting President Suharto was planning a trip to Tokyo to seek economic aid. It also became known that such a visit had been arranged to start on March 28 and that Alamsjah, as Suharto's personal representative, had already met several times with Japanese Prime Minister Sato Eisaku to discuss the aid problem and Suharto's visit. ${ }^{17}$ As part of Alamsjah's "advance group," Soedjono was also involved in arranging Suharto's trip. In addition, however, this series of visits in early 1968 provided him with the opportunity to meet Japanese officials, to introduce to them the new face of government in Indonesia now that Sukarno had passed from the scene, and to impress upon them the New Order's interest in improving relations with Japan. 18

The main problems confronting Indonesia in its quest for Japanese aid were apparent in press reports during the early months of $1968 .{ }^{19}$ First, the Japanese government was

\footnotetext{
${ }^{13}$ Inamine Ichiro, Tamai Kenji, and Nakajima Shinzaburo, "Asahan Dam Project no Haikei [Background to the Asahan Dam project]" Indonesia Center, Tokyo, August 8, 1973, mimeo. Walandouw acknowledges having been deeply involved in seeking foreign support for the anti-Sukarno forces during the late 1950s, and has said that he knew Inamine at that time. (Confidential source.)

14 "SPRI dibubarkan, Asisten Pribadi dibentuk," Kompas, June 13, 1968. The other two Aspri named at that time were Major General Suryo Wiryohadiputro and Colonel Ali Murtopo.

15 Kompas, February 3, 1968.

${ }^{16}$ Crouch, Army and Politics, p. 308; David Jenkins, Suharto and His Generals, Indonesian Military Politics 1975-1983 (Ithaca: Cornell Modern Indonesia Project, 1984), p. 23.

17 "Djepang berusaha keras memenuhi permintaan Indonesia," Kompas, January 24, 1968; and "Sato: Djepang akan selesaikan soal kredit kepada Indonesia," ibid., January 26, 1968.

${ }^{18}$ Sofyan Wanandi and J. Soedjati Djiwandono, "Soedjono Hoemardani dan Jepang," in Soedjono Hoemardani: Pendiri CSIS 1918-1986 (Jakarta: CSIS, 1987), p. 82.

${ }^{19}$ See also Franklin B. Weinstein, "The Uses of Foreign Policy in Indonesia" (Ph.D. dissertation, Cornell University, 1972), pp. 634-39.
} 
already being pressured by the United States to contribute one third of the $\$ 325$ million aid package, or about $\$ 110$ million, approved earlier that year by the Inter-Governmental Group on Indonesia (IGGI), a group of Western creditor nations. Second, the Japanese government, though willing to grant low interest credits to Indonesia, was constrained by legal restrictions on the amount and form in which such aid could be given. Moreover, the Japanese-government-during the course of debate on the government budget for the coming fiscal year-was at that time attempting to respond to opposition party complaints regarding Indonesia's alleged misuse of previous foreign aid while also attempting to pass new regulations to permit loans to be extended at lower interest and in larger amounts. As a result, the Japanese government was unable either to make a formal decision on aid, or to give a strong public commitment on the issue.

Alamsjah was aware of these problems, but "chose to give more weight to the optimistic words of his Indonesia lobby friends." 20 He was not alone; in fact, Adam Malik appears to have been one of only a few individuals who advised Suharto that the Japanese were not likely to make an aid commitment even if he (Suharto) personally went to Tokyo. Most advisers, including Soedjono, apparently felt that Japan could not and would not refuse aid if Suharto, who was elevated to full president only days before leaving for Tokyo, himself requested it. Thus, the president departed from Jakarta for a trip to Japan (and Cambodia) on March 28, with the expectation that his Japanese hosts would give him, at the very least, a firm commitment of approximately $\$ 100$ million.

For a president who placed such reliance on the advice of trusted personal advisers, the Japanese reception must have come as a rude shock. Rather than fulfilling Alamsjah's sunny predictions of forthcoming aid, official Japanese representatives met the Indonesian delegation at the airport with warnings not to expect too much during their visit. Upon his arrival, Foreign Minister Adam Malik was met by the Japanese foreign and agriculture ministers, Miki and Nishimura, and told that the decision on aid was up to Suharto and Sato alone. At the same time, Indonesian Finance Minister Frans Seda was met by his Japanese opposite number, Mizuta, who informed him that aid was stalled for the moment for two reasons: first, a change in the OECF's (Overseas Economic Cooperation Fund's) statutory law was pending in the Diet and, second, the Japanese "national account was in trouble." 21 In essence, both Indonesian officials were being told that Indonesia had chosen an inopportune occasion to come to Japan and that circumstances would not permit any formal aid commitment. Although President Suharto remained in Tokyo for three full days longer, attempting to pressure the Japanese government to give aid equal to one third of the total IGGI-approved assistance, the Sato government was unable to respond positively.

Events attending the conclusion of this mistaken journey reflected the high hopes of the Indonesians and their intense frustration at having failed; most of all, it reflected their concern that Suharto had suffered an affront to the dignity of his position. By the end of their fourth day in Tokyo, the Indonesian delegation had decided to express their dissatisfaction with their reception in Tokyo by refusing to issue a joint communiqué before their departure the next day for Phnom Penh. Later that night, for reasons which remain unknown, Soedjono attempted-on his own "initiative," he later claimed ${ }^{22}$ - to salvage the mission by bringing his recent acquaintance, Kimura Takeo, a member of the

20Ibid., p. 635, n. 115.

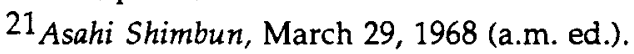

${ }^{22}$ Weinstein, "Notes of interviews," February 26, 1973, p. 7. 
Indonesia lobby and head of the Cabinet Secretariat, to see Suharto. Franklin Weinstein has described the confused situation which followed:

Kimura claimed that Sato had authorized him to say that the Japanese government was now prepared to accept the $1 / 3$ formula. The next morning Malik told Japanese Foreign Minister Miki that if he could confirm the statement of Kimura, Indonesia would sign the communique. But Miki said he had no information corroborating Kimura's statement, and later, as Soeharto was preparing to leave for the airport, Miki told Malik that Kimura had not been sent by Sato. ${ }^{23}$

Two things suggest that this episode represents a premature attempt by Soedjono to exercise the influence which he would possess only later. First, it seems most unlikely that, after four days of declining to give the aid commitment sought by Indonesia, Sato would suddenly have changed his mind that night and authorized someone else to give such a commitment-and the next morning deny having done so. Second, if Soedjono did indeed act alone, i.e., if Kimura was not sent but brought, then Soedjono was trading not only on Kimura's stature, but his own, though it is unclear what could have been accomplished without Sato's explicit approval; after all, Indonesia had been demanding, at a minimum, precisely what Japan could not give-an explicit, public undertaking that approximately $\$ 100$ million in aid would be forthcoming that year.

A year and a half later, Soedjono denied that the trip had been a disaster, or even that it had been primarily an attempt to obtain aid. He described its purpose as "merely to repay the official visit of Sato previously" (in late 1967). ${ }^{24}$ Despite the disingenuous nature of these remarks, his additional comments suggest that he did in fact understand the crux of the situation: "The real problem in the aid negotiations was not at all between Indon[esia] and Japan, but between the Japanese government and the [Japanese] parliament." 25 The "real problem," however, may have been that Alamsjah, Soedjono, and Suharto's other close advisers did not achieve this level of understanding of Japanese domestic politics until after they had undertaken the journey. The incapacitation of the Japanese government in late March, caused by domestic political struggles during the annual budget talks, was wholly predictable and could easily have been foreseen by more experienced officials.

In the incident, the Tokyo government suffered equally from a lack of understanding of the Jakarta government's mode of operation. Sato, as well as Suharto, was embarrassed by the failure of the trip, since he had promised Suharto several months earlier that Japan would give the aid requested at that time by the Indonesian president. He had tried to forestall the trip, but had relied on formal channels of government-to-government communication. As a result, Sato's message was not passed on to Suharto by his most trusted advisers-Generals Alamsjah and Soedjono-but by Malik and Seda, political party figures whose advice he was apparently less inclined to accept.

Despite the fact that Soedjono had concurred in Alamsjah's optimistic pre-visit assessment of the likelihood of obtaining aid, the trip was later characterized by an Opsus

\footnotetext{
23Weinstein, "Uses of Foreign Policy," p. 637, n. 119.

${ }^{24}$ Weinstein, "Notes of interviews," December 10, 1969, p. 11; Soedjono maintained exactly the same position four years later, saying that "It was just a trip to reciprocate [the] earlier Sato visit. Aid was discussed, but that was not the purpose of the trip." Weinstein, "Notes of interviews," February 26, 1973, p. 7.

${ }^{25}$ Ibid., December 10, 1969, p. 11.
} 
source as "the worst of Alamsjah's many blunders," 26 and Soedjono, as the junior assistant, escaped blame. In the course of the next year, the two men became increasingly distant as Alamsjah apparently considered it unfair that Soedjono was gaining influence at his expense. Alamsjah admitted as much the following year when asked about the already evident split between him and his former junior colleague. He became very "agitated" by mention of this issue, and, directing his criticism at Soedjono's spiritual reputation, complained "that Sudjono is crazy, that he is not intelligent, that he is just a dukun." 27

The year following Soedjono's appointment to the president's redesigned personal staff was a busy and controversial one. In July 1969, Kubota Yutaka presented him with the results of Nippon Koei's preliminary investigation into the status of the Asahan project. Soedjono, in turn, presented the findings to Suharto, who is reported to have ordered that the project be carried out, as long as its development did not harm the national budget or disrupt the flow of foreign aid into Indonesia, i.e., as long as its development was funded by private foreign capital. Despite Suharto's support, however, Kubota was unable to obtain contracts for "more specified studies" until May of the following year. ${ }^{28}$ According to interested Japanese sources, Soedjono and Jan Walandouw assisted Kubota and Nippon Koei in obtaining this contract. ${ }^{29}$ In July 1970, Nippon Koei was awarded a contract by the Indonesian government, to be funded with $\$ 800,000$ from the OECF, to carry out a study of the suitability and proposed design of hydro-electric generating plants at two locations on the Asahan river. ${ }^{30}$ Although there does not seem to have been a great deal of progress over the course of the next two years, the requirement that the project's financing not be drawn from Indonesia's national budget or from scheduled foreign aid, and the obvious impossibility of private Indonesian investors supplying the funds, cleared the way for Soedjono to become more actively involved.

One of his first public activities as an Aspri was to negotiate the release from jail in Tokyo of two businessmen accused of breaking Japanese law. The two men had been working for the Mexim Company, a subsidiary of PT Mantrust, which had been established in May 1967 in order to facilitate Japanese aid-assisted exports to Indonesia; most of its share capital was held by an Indonesian-born Japanese businessman Kida Namio. Kida and Santoso Sutantyo, an Indonesian working for Mexim, had arranged, in 1967, to export two machines for making artificial rice, officially valued at 640 million yen, from Japan to PT Djaya, another Mantrust subsidiary, in Jakarta. By declaring the price of the machinery to be an inflated 900 million yen, they were able to obtain a clear profit of 260 million yen which they then converted to US dollars on the Hong Kong foreign exchange market. ${ }^{31}$ On August 11, 1969, Japanese police arrested the two businessmen on charges of violating Japanese trade and foreign exchange laws, since they had manipu-

\footnotetext{
${ }^{26}$ Weinstein, "Uses of Foreign Policy," p. 635, n. 115.

27 Ann Gregory, "Notes of interview with Alamsjah," June 12, 1969.

${ }^{28}$ Nishihara, Japanese and Sukarno's Indonesia, p. 122, n. 9; "Projek Asahan pasti dimulai tahun 1973," Kompas, April 10, 1972; "Matinya air terdjun sigura-gura," ibid., April 14, 1972.

${ }^{29}$ Inamine, Tamai, and Nakajima, "Background to Asahan."

${ }^{30}$ Siahaan, Sejarah pembangunan proyek Asahan, p. 242.

31 "Pengusaha Indonesia ditahan polisi Djepang karena manipulasi 260 djuta yen," Kompas, August 13, 1969. The source of this article was acknowledged as Kyodo news service.
} 
lated the export price of goods in order to claim an amount of yen-denominated aid in excess of that to which they were entitled.

Over the course of the next two months, Soedjono visited Japan several times, initially to seek the release of the two businessmen, and later to attempt to minimize any resulting damage to Indonesian-Japanese relations. ${ }^{32}$ Reportedly, as a result of Soedjono's intervention with the Japanese minister of finance, Fukuda Takeo, and the prime minister, Sato Eisaku, the businessmen were released about one month following their incarceration. Furthermore, as a result of Soedjono's patronage-and that of fellow Aspri Suryo and State Logistics Board (Badan Urusan Logistik, Bulog) chief Achmed Tirtosudiro-PT Mantrust continued to prosper. ${ }^{33}$

The following year, Suharto reacted to the continuing charges of corruption in his government by appointing a Commission of Four (Komisi IV) to investigate the matter. Its report was never published officially, but its contents did appear over the course of several days in a Jakarta newspaper. The first of those reports singled out PT Mantrust as one of a handful of companies requiring special attention because of its questionable practices. ${ }^{34}$ Approximately two weeks after the publication of the commission's findings, Suharto issued a presidential decision in which he declared explicitly that the Aspri did not have "executive power," 35 possibly hoping thereby to reduce the public attention to and concern with the many roles of the Aspri.

Less than two years later, in 1972, students and newspapers again began making accusations of corruption within the regime, this time with increasing vehemence and with the support of certain powerful military figures. Soedjono Hoemardani was once more among their most prominent targets. His principal offense in the eyes of his critics, this time, was not so much alleged impropriety in domestic financial affairs as his admittedly large role in facilitating-and exploiting-the inflow of Japanese investment, which grew rapidly in the early 1970 s.

The early 1970s were an especially active time for him in the area of Japanese investment, not only in facilitating the efforts of eager investors, but in encouraging them to invest in a way which suited the Indonesian government's objectives. Among the largest and most significant investments in which he was involved were the Asahan project and the establishment of a new oil export company to serve the Japanese market, the Japan Indonesia Oil Company (JIO).

As noted above, Suharto had approved the continued development of the Asahan project in 1969, after Soedjono presented him with the results of a Japanese study. In 1971, probably early in the year, Nippon Koei completed the second stage of the research

\footnotetext{
32"Sudjono Humardani minta kepada Menteri Keuangan Djepang," Indonesia Raya, September 10, 1969; "Sudjono Humardani di Djepang," ibid., September 17, 1969; and "Sudjono Humardani akan menemui Sato \& Fukuda," ibid., September 22, 1969. Soedjono later claimed that his only reason for going to Japan was to discuss problems relating to Indonesia's foreign debt. He claimed that the only action he took with regard to the Mexim/Mantrust case was to write a letter to the Indonesian ambassador in Tokyo asking him to assist the Indonesian citizen involved in the case. "Walaupun tjuma sandalan, semua pintu terbuka baginya," Ekspres, May 10, 1971, p. 12.

${ }^{33}$ Crouch, Army and Politics, p. 289.

${ }^{34}$ Sinar Harapan, July 18, 1970, p. 2.

35 “Tugas dan wewenang ASPRI Presiden," Indonesia Raya, August 5, 1970.
} 
which it had begun the year before. ${ }^{36}$ In April 1971 Soedjono traveled to Japan to meet Prime Minister Sato and to seek a wide assortment of aid. On his return, he was credited with having obtained not only 150 tons of rice and $\$ 155$ million in export credits, but also a commitment to provide financing, at a cost of $\$ 500$ million, for the entire Asahan project, including a seaport, the aluminum smelter, and the hydro-electric generation plant. He reportedly convinced Sato that Japan should assist Indonesia to develop the project as "a monument of friendship of the type of the Aswan Dam built by Russia in Egypt." 37

In early 1972, Indonesia put the project up for public bid, with the expectation that several companies-in particular, five Japanese and two American-would participate in the bidding process. However, by the closing date of July 15, no firms had submitted bids, ${ }^{38}$ because they objected to the requirement that they agree to develop both the power plant and the aluminum smelting facility. The US firms considered the former uneconomic, and had little hope of securing government subsidized financing for the combined project. The Japanese firms were in a particularly difficult position because of the impending presidential election within the ruling Liberal Democratic party (LDP) in which Sato would be replaced, and the commitment he had made in 1971 to support the project would thus be threatened. In light of the enormity of the total investment which the project would require, and Indonesia's insistence that the entire project be developed as a package deal, it was clear that the foreign firms would be compelled to form a joint venture. Reportedly, one of the firms had suggested this to Soedjono, and two of the largest Japanese firms, Sumitomo and Mitsubishi, were interested in forming a joint venture with the two US aluminum companies interested in the project, Alcoa and Kaiser $^{39}$

In August, following an informal extension of the bidding period and the change of leadership in Japan, it was announced that Soedjono had gone to Japan to discuss the project with the Japanese companies which remained interested and with the new Japanese government. ${ }^{40}$ The main obstacle to any agreement at this point was the demand of the Japanese companies that their government extend them low interest loans to fund the construction of the hydro-electric portion of the project, and the as yet unknown readiness of the new LDP government, under Tanaka Kakuei, to do so. Soedjono and the special mission which he headed remained in Tokyo for about one month before returning to Indonesia in mid-September. Still, no announcement was made regarding the progress of his negotiations. Soedjono and his "Special Team" then returned to Tokyo for at least three more weeks. Finally, in early October while Soedjono was still in Tokyo, it was announced that the Japanese government was prepared to grant the Japanese companies loans on easy terms. About a week later, representatives of the five Japanese firms arrived in Jakarta and delivered a letter to the Indonesian

\footnotetext{
36"Proyek Asahan dibagi dalam 5 kontrak detail," Kompas, December 31, 1973.

37Wanandi and Djiwandono, "Soedjono Hoemardani," p. 83; and "Walaupun tjuma sandalan, semua pintu terbuka baginja," Ekspres, May 10, 1971, pp. 14-15.

38"Proyek Asahan: Setelah 67 tahun," Topik (July 1975), p. 34.

39“Proyek Asahan pasti dimulai tahun 1973," Kompas, April 10, 1972.

40 Soehoed, Asahan, p. 245; and "Indonesia optimis proyek Asahan dimulai awal th. 1973-Aspri Presiden Sudjono Humardani berangkat ke Jepang," Kompas, August 29, 1972.
} 
government, in which they declared their readiness to begin discussions of the project as a "package deal" in accordance with the requirements of the Indonesian government. 41

Despite the apparent agreement reached between the government of Indonesia and the Japanese companies, and between the Japanese companies and their government, 42 negotiations continued through 1973 regarding a wide range of technical and financial issues affecting the future development and operation of the project. However, following his success in obtaining the broader commitments needed before this second round of talks could proceed, Soedjono's role appears to have diminished. Not until the Basic Agreement was signed on January 2,1974,43 did he appear as publicly involved in the project, and then only as an observer; by that point, Soedjono's "Special Team" had turned the project over to Mohamad Sadli's "Technical Team."

Soedjono's involvement in the negotiations for the controversial 1972 Japanese "oil loan," worth $\$ 300$ million, are less clear than his role in the Asahan project. However, according to one account, he "was the key figure handling negotiations on the Indonesian side," and in the end, "[Minister of Foreign Affairs] Fukuda, [Minister of International Trade and Industry] Tanaka and Sudjono became partners ... [in] the new company Japan Indonesia Oil" which was established as an alternative to the existing Far East Oil Trading Company (FEOT) both of which were dedicated solely to the export of Indonesia's oil to Japan. ${ }^{44}$ The deal's significance lay in Japan's acquisition of a guaranteed long term supply of crude oil, while its controversiality lay in Indonesia's receipt of a large amount of loans outside the IGGI-approved-and therefore controlledassistance.

Discussions, which had begun in 1970, reached their peak during the first half of 1972 and, because of the coming change of leadership in Japan's ruling Liberal Democratic party, were affected more than usual by the vagaries of LDP factional politics. Specifically, Tanaka Kakuei opposed the deal because he feared that his rival for the LDP presidency, Fukuda Takeo, stood to gain financially from it. As the result of a compromise facilitated by Kamiya Shotaro, the president of Toyota Motor Sales who had been attempting without success for several years to lend $\$ 50$ million to Indonesia in exchange for oil, Tanaka Kakuei and Fukuda Takeo agreed to proceed with a loan package consisting of a $\$ 200$ million soft loan from the OECF and a $\$ 100$ million private loan from Toyota. In exchange, Indonesia agreed to provide 58 million kiloliters ( 3.65 million barrels) of oil over the next ten years, in addition to that for which Japan had already contracted. This

\footnotetext{
41 "Sudjono Humardhani bicarakan proyek Asahan," Kompas, September 13, 1972; "Pengusaha-pengusaha Jepang akan teruskan proyek Asahan," ibid., October 3, 1972; and "Jepang setujui prinsip2 pokok pembangunan proyek Asahan," ibid., October 12, 1972.

${ }^{42}$ The Indonesian government does not appear to have made a serious attempt to cultivate US interest in the project. The chief usefulness to Indonesia of having two US companies express some interest was the leverage it gave in bargaining with Japan. See, for example, Adam Malik's report following his return from New York and Tokyo in which he declared that the US companies would continue to participate in the project's development, and the Japanese firms, therefore, no longer had any reason not to continue. "Adam Malik: Proyek Asahan bukan persoalan lagi," ibid., October 2, 1972.

43"Perjanjian-dasar proyek Asahan ditandatangani," ibid., January 3, 1974.

${ }^{44}$ Wayne Robinson, "The Politics of Japanese-Indonesian Energy Cooperation, with Particular Reference to the Period 1972-1976" (Ph.D. dissertation, Monash University, 1980), ch. 4. The following discussion of the oil loan negotiations are drawn from the descriptions provided in the aforementioned thesis, as well as in Jean Bush Aden, "Oil and Politics in Indonesia, 1945-1980" (Ph.D. dissertation, Cornell University, 1988), pp. 358-71. See also Petroleum News Southeast Asia (June 1972), p. 6; (September 1972), pp. 4-5; (December 1972), p. 11.
} 
oil was to be sold to its Japanese customers through a new company, JIO. The agreement concluding this deal-hailed as the "most important agreement anywhere between an oil consuming and an oil producing nation" 45 - was signed by President Suharto in Tokyo on May 9, 1972.

According to Wayne Robinson, two features of the negotiations were "striking." First, they were "conducted almost entirely outside formal diplomatic channels," and second, "the attitude on both sides was generally cooperative rather than in the nature of formal state-to-state dealings.... The talks were ... organized informally and on a personal basis." Jean Aden emphasizes the dominant role of Suharto himself in these negotiations, as opposed to Ibnu Sutowo's previously unfettered activity in oil-related fundraising. All these features conform to the style of operating in which Soedjono was typically engaged on behalf of the Indonesian government.

Soedjono indirectly confirmed both the informal nature of the talks and the centrality of his own role as the president's personal representative, when he commented that,

"The idea [to establish an alternate channel for oil exports to Japan] was revived around the end of 1971 when I went to Tokyo and talked with Fukuda-as well as Tanaka." 46

Although he minimized the impact of Japanese politics on the arrangement of the oil loan, Soedjono's comments did reflect the conflict which engaged the Indonesian negotiators-all close advisers of Suharto-in late 1971, as well as the changing nature of the negotiations. Initially, in 1970, talks had been carried out between Tanaka Seigen, a Japanese oil businessman, and Ibnu Sutowo. However, Tanaka had soon gone over Ibnu's head, because of Ibnu's opposition to the creation of another oil export channel in addition to FEOT which he had established in 1965. In order to contact President Suharto directly, Tanaka went through Alamsjah, still head of the State Secretariat, but this damaged the previously good relations Alamsjah had enjoyed with Ibnu. In the ensuing confrontation, Sutowo is said to have "swung strongly in support of the anti-Alamsjah group around the President," 47 which, as we have seen, included Soedjono as a leading member. In December 1971, Suharto finally removed Alamsjah from his position and in early 1972 sent him as ambassador to the Netherlands.

Soedjono was defensive of Ibnu's role, and clearly satisfied that his rival for power in Suharto's inner circle and in Indonesia's relations with Japan finally had been removed. Less than a year after the signing of the agreement, he claimed:

The problem was that Tanaka Seigen and Alamsjah were involved in dirty dealing. What they wanted to do amounted to a revival of the old order practices of corruption. Tanaka Seigen wanted to buy Ibnu. We won't allow Tanaka Seigen to come to Indon[esia] anymore. And as for Alamsjah, you can see that he has been made an ambassador. ${ }^{48}$

However, he also minimized the effect of Ibnu's opposition to the loan arrangement, saying that

45 Petroleum News Southeast Asia (December 1972), p. 11.

46 Weinstein, "Notes of interviews," February 26, 1973, p. 2.

47 Robinson, "Politics of Japanese-Indonesian Energy Cooperation," ch. 4.

${ }^{48}$ Weinstein, "Notes of interviews," February 26, 1973, pp. 1-2. 
"Ibnu is just an instrument, an implementor-he must carry out [the] President's decisions. . . . it doesn't matter what Ibnu's own feelings might have been. . . ${ }^{49}$

Though frequently described as one who preferred the background shadows to the glare of the limelight-in contrast to his colleague and fellow Aspri, Ali MurtopoSoedjono was not entirely unwilling to speak about the nature of his work and his ties to Japan and its leaders. These topics, among others, were treated in a lengthy news magazine article about Soedjono, 50 based primarily on a wide-ranging interview with him. In the article, which appeared in the weekly Ekspres, connected to Ali Murtopo's Opsus (Operasi Khusus, Special Operations), Soedjono's friendship with Japanese leaders and the strength of his ties with them was something of which he was clearly proud. According to Ekspres, Soedjono was known among his colleagues as the "troubleshooter' ekonomi RI," and was told by Japan's Prime Minister Sato that he was "the bridge between the two countries"; following their meeting in April 1971, Soedjono said, Sato asked him to come to Japan more frequently. Soedjono stressed the importance of maintaining strong personal relations not only with the Japanese prime minister, but with a wide spectrum of Japanese leaders. He emphasized that, because he knew not only Prime Minister Sato but also ministers and important figures in the Diet, the bureaucracy, and society in general, he was able to accomplish a great deal; a case in point, he claimed, was the change in Japanese law which permitted Japan to agree that Indonesia's debts could be repaid over a thirty year period without interest.

Two of his former colleagues at the Center for Strategic and International Studies (CSIS) emphasized that Soedjono's role in Indonesia-Japan relations was played out at both formal and informal levels. Moreover, they said, he maintained a wide range of political contacts, including those with all factions of the ruling Liberal Democratic party, as well as the opposition Socialist and Komeito parties. In addition to his acquaintances in the Diet, he is said also to have cultivated good ties with the bureaucracy, mass media, and, naturally, with Japanese business. ${ }^{51}$

A multifaceted approach to the conduct of relations with Japan, Soedjono believed, was not only useful, but necessary. He saw the Japanese corporations' foreign operations and strategy as inextricably enmeshed in the Japanese government's making of foreign policy. Such behavior demanded that the Indonesian government adopt a different approach to relations with Japan than it practiced towards other countries. Drawing upon several years' experience gained from heading such a "different approach," he wrote in 1974:

When dealing with Japan, we are faced not just with the government but also with the managers of the giant corporations who are very dominant in the formulation of every foreign policy move... The Japanese industries outside Japan will gradually control Japan's foreign policy decisions and these decisions will be based purely on economic considerations while involving the Japanese government in providing political security. It is seen here how difficult it is to solve problems arising between Japan and other countries, including Indonesia, if we confine ourselves to diplomatical moves.... It is obvious that conventional diplomacy will not be able to

\footnotetext{
$49_{\text {Ibid., p. } 2 .}$

50 "Walaupun tjuma sandalan, semua pintu terbuka baginya," Ekspres, May 10, 1971, pp. 12-18.

51 Wanandi and Djiwandono, "Soedjono Hoemardani," pp. 83-84.
} 
respond to challenges arising in the relations between Japan and Indonesia.... The only way out is a diplomacy which is more comprehensive in substance and channels because we deal not just with the Japanese government but also with the Japanese industries outside Japan. ${ }^{52}$

Soedjono made no apology for his role in facilitating the flow of private Japanese capital into Indonesia. He explained his views this way:

Try to imagine, there is an Indonesian businessman who has no capital at all. But there is a Japanese businessman who is willing to give him a loan without interest. This means that the Indonesian businessman is able to participate in the venture with him. Of course, if the Indonesian businessman cannot afford even 10 percent of the capital, how can you complain if the Japanese have a monopoly? That is the reason why many Indonesian businessmen today are still minority shareholders. Later it will slowly come into line with the government's regulations. . . 53

He was clearly aware that others might not approve of his "go-slow" attitude toward the development of indigenous enterprise. In 1969, he told an interviewer:

The position of foreigners in our economy is only temporary, because we need their help now. We are confident that ultimately it will all be turned over to us. And furthermore, even now, it is not accurate to say that foreigners control our economy. They are playing a certain role at our invitation-nothing more than that. ${ }^{54}$

Nor did he express any concern that non-pribumi Indonesians may have benefitted from the government's economic policies more than pribumi Indonesians:

We offer an opportunity to anyone who wishes to join in development. Those who have a plan and a concept/idea. It doesn't matter if they are pribumi or not. All capital must be exploited regardless of where it comes from. . . 55

Nevertheless, one of the Indonesian businessmen whom he held in high regard and whom he successfully assisted in establishing profitable ties to Japanese business was a pribumi, Mohammed Gobel. When asked by Franklin Weinstein in 1973 if there were any businessmen with whom it would be helpful to talk, Soedjono told him, "You don't want to see people who are not satisfied. All they will do is complain." The first person whom he mentioned, and no doubt someone who was well satisfied, was Gobel. ${ }^{56}$ Gobel was the owner of a radio and television assembling company, PT National Gobel, which assembled the products of the Japanese electronic company Matsushita with the brand name "National." In December 1972, Matsushita agreed to give, through its Indonesian

\footnotetext{
${ }^{52}$ Soedjono Hoemardani, "Indonesia-Japan Relations in the Future-A Strategic Review," The Indonesia Quarterly 2, 2 (January 1974): 9-10.

53 “Tjoba toh, ada orang Indonesia jang sama sekali tidak punja kapital. Tapi ja ada sadja pengusaha Djepang jang memindjamkan tanpa rente. Maksudnja supaja pengusaha Indonesia itu bisa ikut dalam usaha bersama. Lha kalau $10 \%$ sadja dari kapital harus disetor orang Indonesia tidak mampu, bagaimana bisa menjalahkan kalau Djepang pegang monopoli. Itu sebabnja banjak pengusaha Indonesia jang andilnja kini masih dalam taraf minoritas. Nanti pelan-pelan sesuai dengan peraturan Pemerinta...." "Soedjono Humardhani tentang orang Jepang," Tempo , January 22, 1972, p. 51.

${ }^{54}$ Weinstein, "Notes of interviews," December 10, 1969, p. 19.

55 "Kita memberikan kesempatan bagi semuanya yang mau turut membangun. Mereka jang punja rentjana dan konsep. Tidak pandang bulu, apakah ia pribumi atau bukan. Semua modal harus dimanfaatkan darimana datangnja-pun..." Ekspres, May 10, 1971, p. 16.

56 Weinstein, "Notes of interviews," February 26, 1973, p. 7.
} 
partner, a television studio and broadcasting station worth $\$ 500,000$ to the city of Ujung Pandang to service the region of South Sulawesi. Perhaps it was not a coincidence that Gobel's company owned a television assembling plant in that city. ${ }^{57}$

When questioned directly about his role in the movement of Japanese capital into Indonesia, Soedjono first insisted that, "All kinds of businessman come to see me-not just the Japanese," but then admitted that, "Naturally, quite a lot of the people who come here are Japanese, because our relations are good." Regarding specific functions he performed for the foreign businessmen who came to see him, he mentioned the following:

Usually they have their own [partners] in mind. But sometimes we tell them if someone is good or bad, or introduce them to a good partner.... The condition of our bureaucracy is not so good-sometimes [it] takes a long time to get permission from various gov[ernmen]t agencies. So we try to smooth the way, speed things up. ${ }^{58}$

Although Soedjono saw no harm in relying on Japanese capital to accomplish those goals which Indonesia could not yet achieve on its own, an increasingly large number of Indonesians disagreed. Toward the end of 1973, CSIS hosted the first Japan-Indonesia Conference, intended, at least in part, to allay the public's fears that Soedjono and his allies were selling out the country to the Japanese. As honorary chairman of CSIS and head of the Indonesian group attending the conference, Soedjono alluded in his opening speech to the atmosphere in which their discussions would take place:

As far as Indonesia is concerned, the "timing" [of the conference] is also proper considering that the people is actually engaged in open discussions regarding foreign investments, including that of Japan, in the context of development strategy of Indonesia still seeking for an equilibrium. 59

Since part of its goal had been to allay the fears of the public, the actual effect of the conference can only be considered ironic. According to two of Soedjono's CSIS associates, the three-day affair was perceived by many as an inflammatory symbol of his links to Japan, and only reinforced the view of those who felt that he was too friendly with the Japanese and too willing to serve their interests. 60

Public opposition to what was perceived as the increasing dominance of foreign capital in the Indonesian economy was concentrated among the university student population and certain elements of the press. These groups tended to focus on the growing role of Japanese capital in Indonesia and of Soedjono as its accessory. In late 1973, in Jakarta and Bandung, students led the mounting public opposition. Francois Raillon, who studied the student movement during this period in detail, offers a concise picture of Soedjono's place in those events:

\footnotetext{
57"Jaringan Si Gobel di Sulawesi," Tempo, December 23, 1972.

58 Weinstein, "Notes of interviews," February 26, 1973, p. 5.

59 [sic] Soedjono Hoemardani, "To Promote Good Relations between the Republic of Indonesia and Japan," in Japanese-Indonesian Relations in the Seventies, Proceedings of the First Japan-Indonesia Conference, 6-8 December 1973 (Jakarta: CSIS, 1974), pp. 9-10.

${ }^{60}$ Wanandi and Djiwandono, "Soedjono Hoemardani," p. 89.
} 
Throughout the months of November and December, demonstrations against foreign capital and the Aspri multiplied ... among [the Aspri] Soedjono Hoemardani in particular was regarded as the head, indeed the $d u k u n$, of the Japan lobby. 61

The unpopularity of his position was reflected in the burning of his effigy and that of Japanese Prime Minister Tanaka Kakuei on several occasions by university students in Jakarta and Bandung. ${ }^{62}$

In addition to finding himself at odds with a large segment of public opinion as a result of his extensive and informal contact with Japanese businessmen, Soedjono's activities also brought him into conflict with other contenders for power in the president's circle of close advisers. Again, the situation which emerged has been most succinctly described by Raillon:

Indeed, during this period [1972-1973], a struggle for influence, if not for power, took shape around President Suharto between two groups, which, to simplify, can be called the "American group" and the "Japanese group." The first, composed of technocratic ministers and certain generals, ... was inclined toward a relative revision of the mode of development which had been followed until that point ... while the second was encouraged by the Aspri, ... such as Generals Ali Murtopo and Soedjono Hoemardani, and supporters of the continuation of development finance with foreign aid, particularly from Japan. ${ }^{63}$

Following the anti-Japanese riots of January 15, 1974, which coincided with Tanaka's visit to Jakarta, Suharto disbanded the Aspri in order to calm public criticism of his assistants' undue influence. However, Soedjono was quickly reappointed to two other official positions. One was as a member of the Economic Stabilization Council, set up to review economic policies of the cabinet and the National Development Planning Board (Bappenas); this appointment was interpreted, at least by some, as "re-entry via the back door to the political-economic arena." 64 Second, pursuant to presidential decisions No. 25/1974 and No. 102/M/1974, he was installed as one of four Inspectors General of Development on July 23, 1974.65 Moreover, at the time, his personal closeness to President Suharto was not expected to diminish, as the relationship between them was so personal and long standing.

\footnotetext{
61 'Tout au long des mois novembre et decembre, les manifestations, les prises de positions se multiplient contre le capital étranger et contre les Aspri ... dont notamment Sujono Humardhani, considéré comme le chef, voire le dukun 'mage' du lobby japonais." François Raillon, Les Etudiants et l'Ordre Nouveau: Politique et Idéologie du Mahasiswa Indonesia (1966-1974) (Paris: Association Archipel, 1984), p. 95.

62Ibid., p. 100.

63"En effect, durant cette periode [1972-1973], se dessine autour du President Suharto une lutte d'influence, sinon une lutte pour le pouvoir, entre deux clans, que l'on peut appeler pour simplifier le 'parti américain' et le 'parti japonais.' Le premier, composé des ministres technocrates et de certains generaux...est favorable à une relative révision du mode de développement mène jusque là, tandis que le second, animé par les Aspris. ... tels que les generaux Ali Murtopo et Sujono Humardhani, et partisan du maintien d'un développement finance avec l'aide d'étranger et notamment du Japon." Ibid., p. 85.

${ }^{64}$ Eileen Tang and Yong Mun Cheong, "Indonesia in Focus," in Southeast Asian Affairs 1975 (Singapore: ISEAS, 1975), p. 51.

${ }^{65}$ M. Sudibjo, ed., Indonesia dan Dunia Internasional 1975 (Jakarta: CSIS, 1976), p.225, citing Berita Yudha, July 19,1974 .
} 


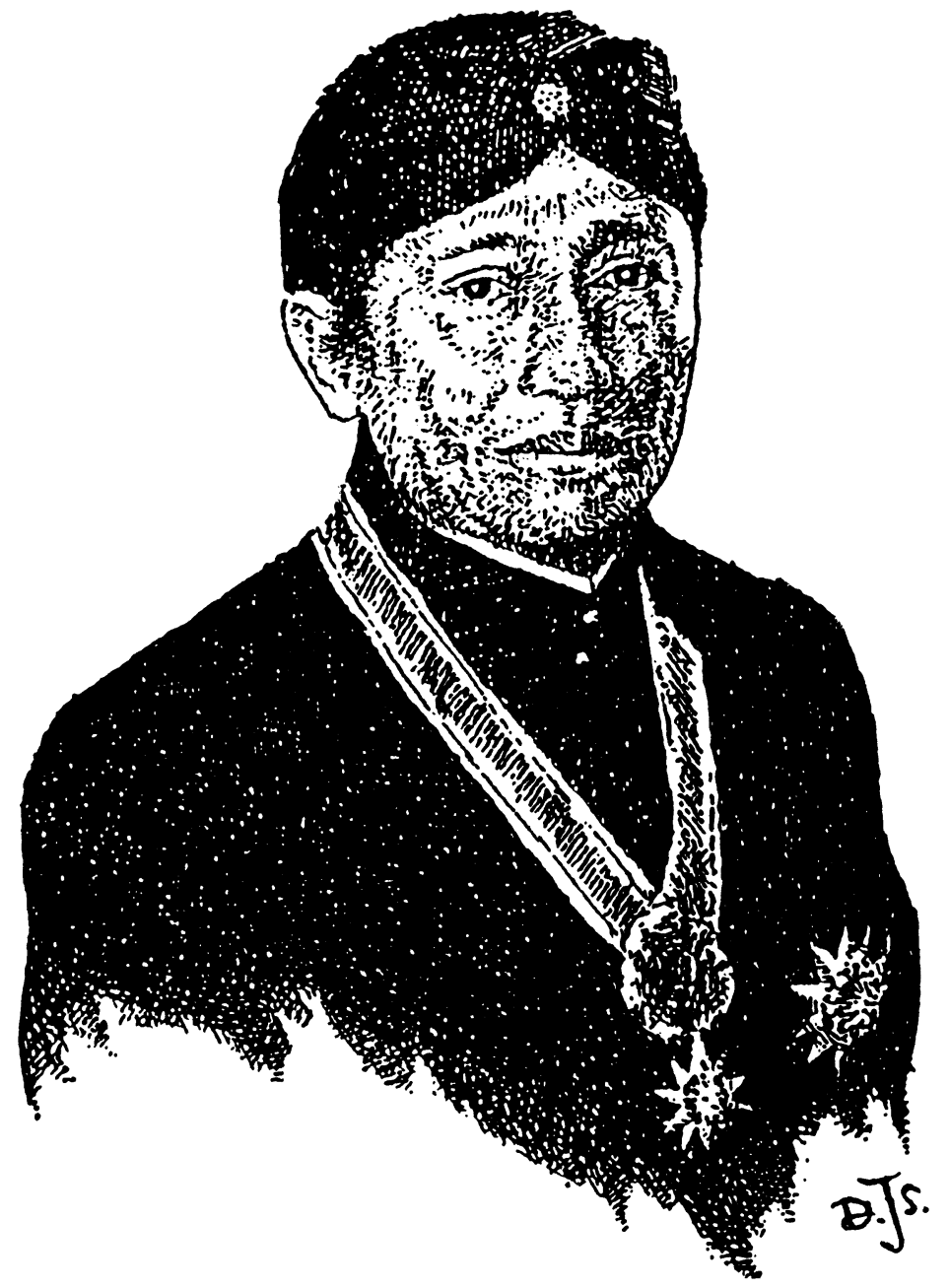

An illumination of Soedjono's personal role in Indonesia-Japan relations during the period 1966-1974 is useful for understanding the process by which those relations were conducted and thereby restored to health, during the formative years of the New Order. Although he played a role which was both interesting and significant, one should not assume that he was the central figure in all facets of Indonesia-Japan relations throughout this period. Most notably, he appears not to have exerted any influence in the massive project in the early and mid-1970s to develop Indonesia's natural gas resources for export to Japan. In this instance, Ibnu Sutowo played the key role.

The unsettled nature of the Indonesian government and bureaucracy in the late 1960s and early 1970s, and the reluctance of the New Order leadership to rely on and trust those officials with backgrounds in party politics, meant that important policy matters tended to be dealt with informally. In this situation, Soedjono was among those who found significant roles to play.His role as personal assistant-cum-representative of President Suharto placed him in a position to undertake initiatives at the highest level of government. The fact that Suharto saw Alamsjah and then, increasingly, Soedjono as his principal intermediaries with Japanese leaders placed the two countries' relations on an informal level. Combined with the inexperience of the Suharto government, this led to embarassment and frustration on both sides in 1968. However, over the course of the 
next five years, Soedjono was able to establish himself in Japanese eyes as an intermediary without equal.

The tendency of the New Order to conduct relations on an informal level extended only to achieving basic understanding on a given issue, usually regarding the general terms of a financial arrangement. Thus, Soedjono played a prominent role in negotiations preceding the signing of the oil loan, but he was not seen to be involved in the subsequent discussions regarding the set up of JIO. Likewise, his role in the Asahan project was limited to negotiating basic agreements-first, with the Japanese government-Sato in 1971 and Tanaka in 1972-to provide financing, and second, with the Japanese firms to bid as a consortium for an all-encompassing contract. Both the actual signing of agreements and the more technical and narrowly financial issues necessary to conclude the agreements and contracts were responsibilities delegated to those in official ministerial positions.

In the years following 1974 there were few public manifestations of Soedjono's involvement in Indonesia-Japan relations. But his activity clearly did not come to a total halt. As someone who relied on a network of personal relationships-beginning with his firm and long-standing friendship with the president-to resolve political, economic, and bureaucratic problems at an informal level, it is unlikely that his ability to operate in these areas was greatly or immediately diminished, or that those who had relied on his assistance needed it less.

Soedjono maintained public ties with Japan throughout the 1970 s and into the mid1980 s by a series of annual Japan-Indonesia conferences sponsored jointly by CSIS and the Japan Institute for International Affairs. In his role as honorary chairman of CSIS, he had the privilege of giving the opening address and setting the tone/theme for each year's meeting. Among the other notable and frequent speakers at these conferences were the chairman of Mitsui, the presidents of Nomura Research and the OECF, as well as various academicians and government advisers. Although these conferences were well publicized affairs, it should be recalled that one of their principal aims was to bring influential and concerned individuals together for informal discussions 66 and reflected Soedjono's concern that Indonesia's relations with Japan must be handled through nongovernmental channels as well as formal, diplomatic ones. ${ }^{67}$

The occasion of Soedjono's death in March 1986, in a Tokyo hospital, provided indications that he had continued to be close to powerful Japanese business and government leaders. Before his body was taken back to Indonesia, many of the Japanese he had known came to pay their last respects; among those who came were the head of Keidanren's Indonesia committee and "high officials from the Ministry of Foreign Affairs." The Japanese ambassador to Indonesia, Muto Toshiaki, not only paid his respects in Jakarta, but accompanied the funeral procession from Soedjono's home in Jakarta to the family's burial site in Janti, his father's village outside Solo. Those who sent condolences to the family included Soedjono's more influential friends and acquaintances in Japan: former prime ministers Fukuda Takeo and Kishi Nobasuke, former Foreign Minister Abe Shintaro, current Minister of International Trade and Industry Watanabe Michi, and the current head of Keidanren, Inayame Yoshiro. ${ }^{68}$

\footnotetext{
66 Wanandi and Djiwandoro, "Soejono Hoemardani," p.87.

${ }^{67}$ Hoemardani, "Indonesia-Japan Relations, " pp. 9-10.

${ }^{68}$ Harry Tjan Silalahi, "Kata Sebuah Riwayat," in Soedjono Hoemardani: Pendiri CSIS, 1918-1986, pp. 1-23.
} 


\section{Michael Malley}

Throughout the first two decades of the New Order, and until his death in 1986, Soedjono played an important, though not an all-powerful, role in the conduct of Indonesia's relations with Japan. The extent of his role depended primarily on his personal closeness to President Suharto, as did the enduring nature of his role. That the scope of his activities narrowed during the latter half of this period (1966-1986), however, owes more to the maturation of the New Order government than to any change in his relationship to the president. 